\title{
A Critical Analysis on the Summary Judgment Based on the Penal Procedural Code of the Republic of Albania
}

\author{
Phd. Luan Hasneziri \\ Tirana First Instance Court of Serious Crimes, Tirana, Albania \\ Email: Iuanhazneziri@yahoo.com
}

Doi:10.5901/ajis.2015.v4n2s2p89

\begin{abstract}
After the fall of the communist system, the new Penal Procedural Code of the Republic of Albania was approved by the Law no. 7905, dated on 21.03.1995 and entered into force on august 1st, 1995. This Code compared to the other Penal Procedural Codes of communism period, is different, as it is contemporary and democratic, aiming to determine procedural regulations on criminal acts judgment, as well as providing defense and warranty of the defendants' rights and freedom along penal process. This Penal Procedural Code provides a new element, the summary judgment, which was not provided before by previous Codes of communism regime. Taking into account that judges, lawyers, prosecutors and other officials of the judiciary, were not familiar with this element, since the very beginning it was a real issue in the context of its accuracy and its right. The goal of this paper is to handle, and summarize the summary judgment in accordance with the Penal Procedural Code provisions of the Republic of Albania. The first case will provide legal procedures that regulate the aggregated decision, provisions provided by Penal Procedural Code. In this case legal provisions will be given, not only merely based on findings, but also on the context of viewpoint, in a critical aspect and issues related to the judiciary practice. The second case we will have to review issues came across in the judiciary practice in Albania related to aggregated decision. Herein after, we will have to review the Unified decision of the High Court no. 2 dated on 29.01.203, as well as some other decisions of the Constitutional court, where their main topic of review is particularly the aggregated decision. Main hypothesis to present in this paper is: Does the Penal Procedural code fully and fairly regulate the aggregated decision? The answer related to this question is No. The code does not fully effectively regulate this procedural element. At the end of this paper, I will provide the achieved conclusions and also the biography where it is based upon.
\end{abstract}

Keywords: summary judgment, penal process, defendants' rights, judiciary practice, fair/right judgment/decision.

\section{Introduction}

Summary Judgment is one of the kinds of special judgments envisaged by the Criminal Procedure Code of the Republic of Albania. Being a special trial, this type of judgment presents its own characteristics in comparison to both the ordinary judgment and the other special judgment that our procedural law provides, and particularly the direct judgment. Our Code of Criminal Procedure, has regulated summary judgment, in four provisions in total, from Article 403 to Article 406 of the Criminal Procedure Code.

The question to be resolved in this case is: what were the reasons so as to provide summary judgment as a special kind of judgment? I think, one of the reasons is the fact that, for a limited number of cases, the preliminary investigations might be complete without requiring further actions during the judicial proceedings to be carried out. For this reason, it is useful for judicial economy that, the evidence collected during the preliminary investigation, not to be repeated before the court again. It is precisely to avoid the repetition of the hearing, the reason why the legislators envisaged summary judgment, which, we should stress that it is carried out, only if the defendant or his legal defender file a request for the development of the trial according to this procedure.

Another reason that has led the legislator to foresee summary judgment as one of the types of special judgment, in my view, is related to the provision of giving the defendant the opportunity to obtain a reduced sentence, in case he is charged with one if he pleads guilty, according to the procedure of summary judgment. This provision is explicitly expressed in the criminal procedural law, which stipulates that, when the court gives a sentence based on summary judgement, it reduces the penalty of imprisonment or fine, in a third of the sentence. (art. 406, point 1 of Criminal Procedure Code of the Republic of Albania, approved by Law No. 7905 dated on 21.03.1995, amended, entered into force on 01.08.1995).

As mentioned above, we can draw to the conclusion that there have been two the reasons that led the legislator to 
provide summary judgment, as one of the types of special judgments:

Firstly: the judicial economy, thus, the acts and evidence already collected during the preliminary investigation procedure not to be reviewed by the court during the judicial proceedings and

Secondly: the chance given to the defendants, if the court finds them guilty, in order to benefit from the reduction of the sentence by one third or to substitute the sentence to life into 3535 years imprisonment, if they file a request for summary judgment.

These two reasons which aim at urging the legislator to provide the summary judgment, have been accepted by the Supreme Court of the Republic of Albania as well, in the Unifying Desicion of the Criminal Section no 02 of 29.01.2003. This Unifying Decision which is obligatory to be applied by all lower courts, when reviewing the same or similar cases, the Supreme Court has stipulated that the scope of summary judgment is not only a benefit for the defendant but it is also judicial economy. (Article 141, point 2 of the Constitution of the Republic of Albania).

Referring to the present case, the Supreme Court in this decision, rebukes the district court of Vlora, which, by developing a trial for a very long period of time, taking new evidence, therefore, repeating all documents and evidence that were taken during the preliminary investigation had taken into account only the interests of the defendants by reducing his by one third the sentence and did not take into account judicial economy, which is one of the reasons for carrying out this judgment, apart from the benefit of the defendants. (Unifying Decision of the Criminal Section of the Supreme Court, No. 02 of 29.01.2003).

In connection with the reason of summary judgment provision, different authors think that this particular type of judgment is the result of an agreement that makes the defendant to be judged under this judicial procedure (Islam $\mathrm{H}$; Panda I and Hoxha A ; "Criminal procedure", Morava Publishing, Tirana, 2007, pages 590-591). I think that this opinion expressed by these authors, it is not completely accurate because having an agreement, there must be the will of the two parties. In this case, it seems like these authors believe that the summary judgment is a consequence of the agreement that makes the defendant with the court, which does not seem fair, as the courts can not be in any case a party in a criminal proceeding and therefore can not set agreements with any of the parties, either the defendant or the prosecutor.

A more accurate view would be, that the summary judgment is a consequence of the defendant's choice, who, by accepting to be judged in the state the acts are, therefore, offering to the court judicial economy, he shall benefit the reduction of his sentence by one third, if found guilty. I think that this was also the opinion that above mentioned authors wanted to express, when they mention that "summary judgment constitutes an agreement accepted by the court, which is intended to shorten proceedings, by reducing to the maximum, the duration of the trial". (Islam H; Panda I and Hoxha A; "Criminal Procedure", Morava Publishing Tirana, 2007, page 591). These authors, with this view, want to say the trial is a choice of the defendant who settles this "agreement" with himself. If the defendants wants to benefit the reduction of one third of the sentence, they must give up the judicial investigation and request that the case to be judged in the state that the acts are.

\section{The legal framework of summary judgment according to the Criminal Procedure Code of the Republic of Albania}

Our Code of Criminal Procedure has regulated summary judgment in only 4 provisions, from Article $403-406$ of it, claiming that it has been carried out a complete settlement of this institute. Provisions anticipating summary judgment, have been liable to two legal changes over the years. Specifically by law no. 8813, dated 13.06.2002, paragraph 2 of Article 404 of the Code of Criminal Procredure has been abolished while paragraph 1 of article 406 of the Criminal Procedure Code was amended and added. (Articles 24 and 25 of Law no. 8813, dated 13.06.2002, "On some amendments to Law no. 7905, dated 21.03.1995 of the Criminal Procedure Code of the Republic of Albania, as amended). Another change was made by Law no. 145/2013, again of point 1 of Article 406 of the Code of Criminal Procedure, which is more of a technical character amendment and came as a result of changes made to the Criminal Code, as well in 2013 (Article 6 of the Law no. 145/2013, "On some amendments to Law no. 7905, dated 21.03.1995 of the Criminal Procedure Code of the Republic of Albania, as amended).

Given the content of the provisions of the criminal procedural law, it is found that the request for a summary judgment, is an exclusive attribute of the defendant, which must be submitted personally by him or by his legal defender, provided with a special power of attorney, in the required form by law. This results from content that the provisions recognizing this right of the defendant, explicitly envisages that the defendant or his representative may request summary trial. (Article 403, paragraph 1 Criminal Procedure Code of the Republic of Albania).

The fact that summary judgment may be requested, only personally by the defendant or his legal defender holding 
a special proxy, in which the defendant should have given explicitly, the right to request summary judgment, is consolidated in the judicial practice of Albania. Thus, in a case of judicial practice, the representative with power of attorney given by the defendant, filed the request to proceed with summary judgment and the court decided to reject the request made by the defender, holding that the defense was not legitimated to file the request as, in the power of attorney, the defendant had not given explicitly the right/power to request summary judgment (decision no. 38, dated 16.04.2013 of the First Instance Court for Serious Crimes in Tirana). Regarding this case, the Court of Appeal for Serious Crimes in Tirana held the same opinion, declaring that the decision of the court of first instance, which had rejected the defense request for summary judgment was fair and grounded. This because the request for summary trial, is an attribute that belongs personally to the defendant, or his defender holding a special proxy where, he should be explicitly given the right and does not belong to the defense of the defendant, without having been given this right explicitly by the defendant (Decision no. 14 dated 03.07.2013 of the Court of Appeal for Serious Crimes, Tirana).

Regarding the content of the provision of Article 403, paragraph 1 of the Criminal Procedure Code, which recognizes the right of the defendant to seek a summary trial, I think, it is not formulated clearly and precisely. This provision is as follows: "1. The defendant or his special representative may request that the case to be concluded, provided that the judicial review has not started". The formulation of this provision poses problems in its meaning, in at least two directions:

Firstly, in this provision, it is not granted, nor explicitly nor implicitly what represents the summary judgment, as one of the types of special trials. I think that the meaning of the summary judgment should be given by the legal provision, since the very beginning in paragraph 1 of article 403 of the code, and not to result in paragraph 1 of Article 404 of the Code.

The second problem this provision contains, has to do with the way it is formulated, causing problems in the logical meaning of the sentence. The question in this case is: How can the defendant request the case to be ended, until the judicial review has not started? So how can he request to terminate his case without even starting the trial?

This logical problem in the design of this provision, has emerged because of the fact that the lawmaker with a single sentence, meant to give both the sense of summary judgment and the deadline within the request for summary judgment which can be filed by the defendant. Willing to give two different concepts, in a single sentence, the legislator has not achieved to give the correct version of neither of them. Thus, by the the content that paragraph 1 of article 403 of the Code of Criminal Procedure, implicitly with the interpretation, we can draw to the conclusion that the request for summary trial, may be submitted by the defendant before the initiation of the review trial, and this is the meaning this provision has, a fact which has been confirmed, without any doubt by the judicial practice as well.

In order to regulate the institute of summary trial in as a complete version as possible, and to avoid any kind of logical and legal difficulties in its meaning, I think, that paragraph 1 of article 403 of the Criminal Procedure Code should be amended in this way:

"The defendant or his special representative (defender) may request that the case to be reviewed in the state the acts are".

By making such a formulation of this provision, not only is the meaning of summary judgment given clearly and laconicly (as the language of the law should be), but also it is avoided any logical difficulty in the sense of this institute of criminal procedure. Also, since, by the content of article 403 of the Code it is not clear up to what stage should the request for summary trial by the defendant be filed, regardless the provision of point 1 of Article 403 of the Code defined it its way, (not so clear and precise), and in spite of the fact that legal practice has manifested no problems in this regard, on the other hand, the law should be as complete as possible. To achieve this, I think that, in article 403 of the Code of Procedure Criminal, after paragraph 1, there should be added another paragraph, point 2, with the following content:

"The request for summary judgment should be made by the defendant or his special representative, before the initiation of the trial".

Once the defendant or his defender has submitted a request in order the case to be judged in the state that acts are, therefore, requesting that the case to be conducted with summary trial, the court gives the prosecutor the right to be heard whether or not he agrees on the request made by the defendant. It should be emphasized that, the opinion of the prosecutor about the request made by the defendant for the summary trial, is not obligatory for the court. Under the law, the court has the exclusive attribute to evaluate and make decisions on whether or not the request for summary trial should be accepted, even if the prosecutor may not agree with this request. (Article 404, paragraph 1 of the Criminal Procedure Code of the Republic of Albania).

Regarding the opinion that the prosecutor should give about the defendant's request for summary trial, we can 
notice that the regulation of this issue in the criminal procedural law is not clear. Court practice has progressed, justly, in the right direction, by seeking the opinion prosecutor on summary trial, immediately after the defendant has submitted an application. On the other hand, referring to the content of the procedural law, the prosecutor gives his opinion, after he presents in a summarised way the results of the preliminary investigation. (Article 405, paragraph 6 of the Criminal Procedure Code of the Republic of Albania).

I think, this provision made by the legislator, is not accurate and should be regulated, because of complicating, without any reason, the judicial session of the summary judgment, regulated by Article 405 of the Criminal Procedure Code. For this reason, I think that the issue of the opinion of the prosecutor about the request made by the defendant for summary judgment, should be regulated since Article 403 of this Code, which must be added to a particular point, and particulaly point 4 , with the following content:

\section{"Upon application of the defendant or his defender for a summary judgment, the court invites the prosecutor to submit the other acts that are not included in the case file of the judgment, as well as to express their opinion on whether or not the submitted request should be accepted".}

As mention above, the body that has exclusive attribute to decide about the acceptance or rejection of the request made by the defendant for summary trial, is the court. The only criterion the law has determined on whether or not the request for a summary trial should be accepted is the solution of the case by the court, in his state of the preliminary investigation acts. If the court finds and determines that the issue against the defendant, can be resolved in the state that the acts are, it decides the acceptance of the request for summary judgment, on the contrary, if not, it rejects it. (Article 404, paragraph 1 of the Criminal Procedure Code of the Republic of Albania).

As per the conditions that must be met for acceptance by the court of the request made by the defendant for summary judgment, a part of judges and prosecutors, but also scholars of law, have expressed the view that a condition required to is that the defendant should plead guilty. To enhance this view, a contribution derives from the way, paragraph 1 of article 406 of the Criminal Procedure Code is formulated, which, before it was amended by Law no. 8813, dated 13.06.2002, stated that, when pleaded guilt, the court reduces sentence by one third.

This view of these authors, has been wrong, as referring to the contents of all the legal provisions regulating this institute, as well as the legislator's scope in this provision, it does not result to have been set as a condition, the guilty plea of the defendant, in order to be accepted by the court his request for a summary trial. This position is also held by many prominent scholars of law, who have long expressed that summary judgment can be applied on any case, if the court finds that it can be resolved in the condition acts are and guilt plea is not a condition. (Islam H; Panda I and Hoxha A; "Criminal Procedure", Morava Publishing House, Tirana, 2007, page 591).

However, the legislator, to avoid any kinds of interpretation regarding the conditions that must be fulfilled for the admission of the defendant's request for summary trial, by law no. 8813, dated 13.06.2002, amended, paragraph 1 of Article 406 of the Criminal Procedure Code, it is specified that, when the court gives sentence, it reduces the penalty of imprisonment or a fine, with one third. This legal amendment removed permanently the dilemma, if, pleading guilty was a required condition so as the request for summary judgment of the defendant to be approved by the court, and it also clarified that, in the judgment of summary trial, the court is entitled to, give, either conviction or the decision of innocence.

The legal rules of the hearing of summary judgment are provided by Article 405 of the Criminal Procedure Code, which is a provision consisting of seven paragraphs or points. Since the beginning I think, the way this provision is drafted is a bad example of the technique of legislation drafting and therefore needs urgent changes. Thus, from seven points or paragraphs of this provision, the first four are unnecessary and can be replaced by a single point or a single paragraph with the following content:

"1. In the procedure of the hearing of summary judgment, the rules that are applicable to ordinary judgment are applied as far as possible".

Such provision with a single point, replaces in a complete manner, all the first four points of article 405 of this Code, which refer only to the rules of the legitimacy of the parties during a hearing of summary judgment, which are the same for both the summary judgment and the ordinary judgment. (Article 405, paragraphs 1, 2, 3 and 4 of the Code of Criminal Procedure of the Republic of Albania). Meanwhile, the rules of the legitimation of the parties in the ordinary judgment, are defined by the Criminal Procedure Code in a detailed manner and the Court will refer to those rules even when the trial is conducted, according to the summary judgment. By making such a provision, which, besides being convenient so far the legislative technique is concerned, it will avoid arising misunderstandings caused by the content of 
paragraph 1 of Article 405 of this Code, which seems to imply that, in the hearing of summary trial, the defendant and his defender should take part necessarily. In fact, by the logical and systematic interpretation to this provision, summary judgment can be carried out and completed even in the absence of the defendant, that is, he might not be present at the hearing and judgment, but his defender with power of attorney, to whom is given explicitly, the right of the defendant to seek summary judgment and to continue and complete the trial in his absence.

Once this legal regulation is settled, where the first four paragraphs of Article 405 of the Criminal Procedure Code shall be replaced by a single point, it is necessary to make the difference of points 5 and 6 of Article 405 of the Code as well as there should be added other points in this article, because, given the content of these points, nothing could be understood about the way how the judicial hearing of summary judgment is carried out. More particularly, sections 5 and 6 of Article 405 of the Criminal Procedure Code have the following content:

"5. Once the request of the defendant is read, the President declares the discussion open .

6. The prosecutor submits synthetically the results of preliminary investigation and expresses his opinion on the request of the defendant".

Through these two points of Article 405 of the Criminal Procedure Code, the legislator claims that summary trial modalities have been regulated. Such a regulation is incomplete and inaccurate, and fortunately, judicial practice has acted itself in the right direction, by "creating" the law and not applying it, as since the law is incomplete and what's more consequently inaccurate, thanks to the judicial practice it has been has been carried out in accordance with the standards of a fair trial.

To return to the content of the law, paragraph 5 of Article 405 of the Code states that, "Once the request of the defendant is read, the President declares the discussion open". In this case the comprehension is not achieved on what request the defendant reads? Making a logical and systematic interpretation of all the provisions leading the institution of summary trial, it seems that it refers to the request for summary judgment, but, this is not the right way to design the law. Moreover, this point of the law provides that, after reading the request of the defendant, the president of the body of judges declares the discussion open.

The question posed in this case is: what discussion does the legislator refer to? It seems as if it refers to the final discussion, but if so, this is a completely unfounded provision, thus, how can the case pass on its final discussion and carried out by summary trial without first reading the request for judgment, and without citing the evidence that allegedly prove the guilt of the defendant. Moreover, although according to summary judgment procedure, there is no judicial investigation and there are no other evidence, it is necessary to give the word to the defendant and his defender, to express their position on the indictment and the evidence presented. Only once the request for trial is read by the prosecutor together with the evidence where the indictment against the defendant bases, and once the defendant and his defender have expressed their position, as well as the court has made a decision for the administration of the evidence presented and the conversion of the investigative file into a judicial file, the President, can declare open the final discussion.

As it can be noticed, the content of paragraph 5 of Article 406 of the Criminal Procedure Code does not give anything precise regarding the procedure of carrying out the hearing of summary judgment and thus there is an urgent need to be amended. Point 6 of this article does not offer any assistance in this regard, except from creating a confusion by predicting that the prosecutor's opinion on the request for summary judgment should be given after having read the request for trial or after having submitted synthetically the results of the preliminary investigation, as the language of the specific law defines in particular. Such a provision, as explained above, is inaccurate, as the judicial practice has justly confirmed that the opinion of the prosecutor to the defendant's request for summary trial is given immediately after the defendant submits the request for summary judgment and not once the prosecutor has presented synthetically, the results of the preliminary investigation.

Finally, the seven points of Article 405 of the Code of Criminal Procedure, six of them, and particularly from point 1 to 6 including, including the latter, should be amended and only paragraph 7 of this article has the right content and achieves the purpose for which it was envisaged. Point 1 to 4 , including the latter, since they are unnecessary, should be removed and replaced by a single point, which is quoted above. Points 5 and 6 of this provision, should be removed altogether, because they provide nothing accurate for the hearing of the summary judgment procedure, by mixing and confusing the phases of the trial and should be replaced with new points, which shall give simply and clearly, the whole procedure of the hearing of summary judgment.

Given the above, I think that, Article 405 of the Criminal Procedure Code, should have the following content: 
"1. In the procedure of the hearing of summary judgment, the rules that are applicable to ordinary judgment are applied as far as possible.

2. The summary judgment hearing begins with the verification of the presence of the parties and afterwards the defendant or his defender submit the request for summary judgment, in accordance with the requirements of Article 403 of this Code.

3. Once the court receives the prosecutor's opinion on the submitted request, it takes a decision on accepting it or not in accordance with the rules provided by Article 404 of this Code.

4. Upon acceptance of the request for summary judgment, the president of the body of judges, invites the prosecutor to express the results of preliminary investigation in a summarised manner and the evidence where it is based on, and invites the defendant and / or his defender, to express their position about the indictment and the evidence.

5. After the speech of the prosecutor and the defendant and / or his defender, the court decides to administer the acts and evidence of the investigation file and invites the parties to the final discussion.

6. When the civil claimant does not accept the summary judgment, the civil lawsuit shall not be judged."

At the end of the trial, according to summary judgment procedure, on the basis of the acts and evidence examined, the court may give a decision on the guilt or innocence of the defendant. This fact has been broadly confirmed for a long time by the judicial practice in Albania, and it is supported by, almost, all scholars of law, but it also results from the content of paragraph 1 of Article 406 of the Code of criminal procedure. (Islam H; Panda I and Hoxha A; "Criminal Procedure", Morava Publishing, Tirana, 2007, page 591). The fact, whether the court in summary judgment, can change or not the legal qualification of the criminal offense, is a controversial issue in the judicial practice, and on this issue we shall discuss further, in the second part of this article.

\section{Problems arising from the judicial practice in Albania concerning summary judgment.}

The first problem emerged in the case law for the summary judgment, has to do with the fact, whether the evaluation of the request made by the defendant or his legal defender is only an attribute of the court of first instance, or this issue can be assessed by the court of appeal and the Supreme Court, which have the right to regulate the consequences, by reducing one third of the defendant's given sentence, in the cases when the court of first instance, unfairly refuses the defendant's request for summary judgment. In this regard, the judicial practice in Albania, is consolidated and has determined that the assessment of the defendant's request for summary judgment, is not an exclusive attribute or right of the court of first instance.

The Court of Appeal and the Supreme Court have the right to assess if, the court of first instance has applied or not the law when reviewing the defendant's request for summary judgment, and if they consider that the Court of the first instance was wrong, the higher courts have the right to regulate the consequences, by reducing the defendant's given sentence, byonea third. For this fact, there are dozens of decisions of higher courts, which have regulated the consequences of wrong assessments made by the courts of first instance, which, unfairly, have not accepted the defendant's request for summary judgment and the restitution of the consequences of higher courts, is made by reducing by one third of the the defendant's sentence given by the court of first instance.

Another debated issue related to the summary judgment, is the question how to assess the defendant's request for summary judgment. Shall the defendant's request for summary judgment, be evaluated as an absolute right of the accused, in the sense that, if the defendant files such a request, he shall, necessarily, in any case, benefit from a reduction by one third of the sentence, if found guilty, or such request, shall not constitute, in every case, an absolute right to the defendant and when the court holds that the case can not be resolved in the state that acts are, it is entitled to reject it, and consequently the defendant shall not benefit the reduction by one third of the sentence, when found guilty?

In connection with this question, referring to the content of the criminal procedural law, the answer would be, no. The request for summary judgment of the defendant, can not be considered as an absolute right of the defendant, as in case the court decides that the issue cannot be resolved with the existing documentation, it (the court), is entitled, even obliged to, to reject the request for summary judgment and therefore the defendant shall not benefit the reduction of the sentence by one third, if found guilty. (Article 404, paragraph 1 of the Criminal Procedure Code of the Republic of Albania).

The content that paragraph 1 of article 404 of the Code of Criminal Procedure reveals, I am convinced that the majority of lawyers, will give the above mentioned answer, that is, the request for summary judgment does not constitute an absolute and unlimited right of the defendant. This request is connected, in each case, with the assessment that the court carries out. If the court considers that the question can be resolved with the existing documentation, it accepts the defendant's request for summary judgment allowing the defendant to gain a reduction of the given sentence by one third. 
On the contrary, if the court does not accept the claim the defendant consequently, does no succeed in gaining the reduction of the sentence by one third.

For that matter, personally, I have a different opinion than the majority of authors. I think that the request of the defendant to seek summary judgment and, consequently, to benefit a reduction of the given sentence by one third, is an absolute and unlimited right of the defendant. Consequently, given that this requirement constitutes an absolute and unlimited right of the defendant, the defendant, in all cases, should benefit from the reduction of one third of the sentence, if he is found guilty, when filed a request for summary judgment. The evaluation of the defendant's request for summary judgment as an absolute right, is not inconsistent with the content of paragraph 1 of Article 404 of the Criminal Procedure Code. This because, the fact that the request for summary judgment, constitutes an absolute and unlimited right for the defendant, resulting, in every case the reduction by one third of the sentence imposed on him, if found guilty, does not mean that the court of first instance, must necessarily, in any case accept the request of the defendant.

Not, when the court of first instance, holds that the issue can not be resolved in the existing documentation, it must decide to reject the request and the case to continue to be carried out under the ordinary rules of judgment, by not allowing the defendant to benefit the reduction by one third of the sentence by the court of first instance. But, in this case, the when the case shall be reviewed by the court of appeal, initiated by the appeal of the defendant, who will certainly appeal to the final court decision of the first instance, because, not for his fault, the request dor summary judgment was rejected, the court of appeal, if it declares guilty the defendant, should apply the reduction by one third of the sentence. This reduction of the sentence by the court of appeal should be made, not because the court of first instance has not applied the law, by rejecting defendant's request for summary judgment, but, for the fact that not for his fault, he was denied a legal right.

The arguments why, I consider, the defendant's request for summary judgment as an absolute and unlimited right, are related primarily to the nature of the summary judgment. The defendant on filing a request for summary judgment, in a voluntary manner, resigns from some basic rights of the criminal justice process, such as the principle of contradiction, judicial debate, the presentation of evidence by him, etc. Because of resigning from these rights, the criminal procedural law, has provided as a "compensation or benefit" to the defendant, the reduction of the sentence by one third, if found guilty by the court.

If, in a specific case, the defendant holds that, he should give up these rights and file a request for summary judgment, but, the court does not accept his request because it considers that the case cannot be resolved on the state that the acts are, then, if, by higher courts the consequences would not be restituted by reducing the defendant's sentence by one third, not for his fault, he would be denied a legitimate right. In this case, not for the fault of the defendant, but because of the incompetence or irresponsibility of the prosecution, the reason for which the court would not be able to resolve the case in the state that acts are, the defendant would be denied the summary judgment and the reduction of the sentence by one third.

The right to benefit the reduction of the sentence by one third would be unlawfully violated, under the circumstance that when the request for summary judgment is submitted by the defendant, the latter, voluntarily, renounces some basic rights of the criminal process, intentionally, in order to benefit from the reduction of the sentence by one third. This means that we are facing an unjust and unfair situation, when one party voluntarily accepts to give up some rights, in order to achieve a certain benefit, whereas, the other party, removes those rights from the first party, but refuses to give the benefit that belongs to it, as a consequenceof the renunciation of its rights.

For this reason, I think, the defendant's request for summary judgment, should be evaluated, as an absolute and unlimited right of him, and as a consequence, the defendant shall be able to benefit, in any case, the reduction of one third of the given sentence, if found guilty. This because, the defendant can not bear the wrongful actions of state authorities, in this case, the prosecution, and give up his rights, while not receiving anything from this waiver of the rights. Such an opinion is also held by the European Court of Human Rights in some of its decisions, including decisions given against Albania, in which the Supreme Court has sanctioned, more than once that the defendant, should not suffer in any case, from the wrongful actions of the organs of the state.

As regards the assessment of whether the request of the defendant for an expedited trial, will be regarded as an absolute right, or a right is conditional on the assessment of the court to resolve the issue in the existing documentation it should be noted that, the case law in Albania, namely, the decisions of the appellate courts, the Supreme Court and even the Constitutional Court, but admit implicitly that, this is an absolute right of the accused. This fact seems obvious, as in all cases, the courts of first instance, did not accept the judgment of the cut, the higher court, the regulated effect, in any case, by reducing a third of the sentence, to All the defendants who sought accelerated proceedings and rejected by the court of first instance. This despite the fact that, so, higher courts have not done on the grounds that the request for 
trial shhkurtuar constitutes an absolute and unlimited right of the defendant, but the grounds have become "hidden ", according to which the courts of first instance erred by not accepting the defendant's request for an expedited trial.

Another issue that has emerged from the case law, in connection with the summary judgment, is the fact, how the court should operate, when a criminal case has several defendants and one or some of them request summary judgment while the others, request to be heard with ordinary trial. Regarding this issue, after the release of the Unifying Decision of the Criminal Section of the Supreme Court no. 02, dated 29.01.2003, which has determined that, in a trial with several defendants it can not be proceeded for several defendants on summary judgment and for others with ordinary trial. The courts in Albania, have previously operated by dividing the cases and continuing the judgment of the defendants who have requested summary judgment, while for the other defendants the case has been redistributed and the judgment has began according to the ordinary trial procedure. (Unifying decision of the Criminal Section of the Supreme Court of Albania, no. 02, dated 29.01.2003).

The problem got more complicated when the court held that, the division of the case was not possible, because that would harm the proving of facts (Article 93 of the Criminal Procedure Code of the Republic of Albania). In such case, for the defendants who have requested summary judgment, the court has rejected their request for summary judgment, not because the case could not be resolved in the state that the acts were, but the fact that according to the Unifying decision of the Criminal Section of the Supreme Court of Albania, no. 02, dated 29.01.2003 we mentioned above, there can not be judged simultaneously both the special judgment and ordinary judgment. (Unifying decision of the Criminal Section of the Supreme Court of Albania, no. 03, dated 29.01.2003).

In these cases, the multiple defendants, when one or some of them, request summary judgment and others seek to proceed with ordinary trial and the court has decided to reject the request of the defendants for summary judgment, because the it estimates that the separation of the case damages the proving of facts, it clearly results that the defendants have eventually lost the right to summary judgment, althrough not for their own fault. When the first instance courts have expressed their opinion, the issue of the refusal of the summary judgment of the the defendants has been regulated, in all cases, by the higher courts, which in any case have regulated the consequence by reducing the defendants' given sentence by one third, always on the "hidden" grounds, under which the courts of first instance have given wrong assessment of the fact, by rejecting the request for summary judgment and not according to the above mentioned by me, where the summary judgment is evaluated as an absolute right of the defendant.

Another issue arising from judicial practice, is the question what should the court do when the process basing on the request of the defendant, has continued under the summary judgment procedure and during the hearing the defendant or his lawyer, claim absolute or relative nullity of the acts or request to obtain new evidence. This situation emerged in several cases in the judicial practice in Albania, has not been resolved yet by the criminal procedural law, which I think is a defect of it. However, despite that, the resolution of this situation is not provided by the law, the consolidated judicial practice in this regard, when during the summary judgment, the defendant claims, nullity of the acts or requires new evidence, the court decides to revoke its decision on summary judgment procedure allow the trial to start from the beginning, according to the rules of ordinary judgment.

The above mentioned opinion held by the case law, is based, among others, on the Unifying Decision cited above as well, which has determined that, when in a trial that is being conducted under summary judgment procedure, the defendant or the defense present claims regarding the validity of the acts, or seek other evidence, the court should revoke a decision concerning summary judgment procedure and continue the hearing according to the rules of ordinary judgment. (Unifying decision of the Criminal Section of the Supreme Court of Albania, no. 02, dated 29.01.2003).

To address the above issue, although judicial practice has not shown any problems, since the the law has not provided the resolution of this issue, I think that, in Article 405 of the Criminal Procedure Code, there should be added a special point at the end of this paragraph, where the resolution of this issue shall be provided by the law and not by the practice. This point should have the following content:

"8. When during the trial that is being conducted under the summary judgment procedure, the defendant or his legal defender, arise claims as to the validity of acts of preliminary investigation or seek to obtain new evidence, the court decides to revoke the decision of the summary judgment and to start the trial from the beginning, based on the rules of ordinary judgment ".

Another quite debated problem in the judicial practice, is the fact that, if and is it possible for the court in a concrete case already being processed under summary judgment procedure, with its final decision, to amend the legal qualification of the criminal offense into another easier or more serious criminal offense that the one previously determined by the prosecutor in the request for trial. In this regard, the judicial practice in Albania, since the entry into force of the Code of 
Criminal Procedure, and until 2012, when decision no. 04 of 2012 was issued by the Constitutional Court, used to have a consolidated acknowledgment of amending of the legal qualification of a criminal offense by converting it into another easier or more serious criminal offense than the one previously determined by the prosecutor.

The problem of changing the legal qualification of the offense, into an easier or more serious one, by a court while carrying out summary judgment procedure of trial cut, came in the judicial practice in Albania, after the publication of the above mentioned decision of the Constitutional Court. In this decision, the Court, among other things, concluded, inter alia, that: "when the courts of ordinary jurisdiction proceed with an summary judgment, a proceeding during which, since the court takes into account only the prosecutor's file, there is no possibility of realization of the right to effective protection by the defendant, change of the legal qualification of the offense by the court, it is contrary to the purpose of this trial ". (Decision no. 04 of 2012 of the Constitutional Court of the Republic of Albania).

As a consequence of this decision of the Constitutional Court, when the courts proceed in a criminal judgment under summary judgment procedure, they can not make the change of legal qualification of the offense, in a different offense from the one set by the prosecutor, in the request for trial, especially, they can not qaulify the offense into a more serious one, because that would violate the rights of the accused in this trial and was contrary to the decision of the Constitutional Court, which, it is known, that it is obligatory to all the courts of ordinary jurisdiction and all other state institutions and the public.

The Constitutional Court in drawing to this conclusion, gives as a main argument, the fact that, with the change of legal qualification that the court carries out, by convicting the defendant for a criminal offense different from the one set by the prosecutor, especially when the defendant is sentenced to a more serious offense, the court violates the defendant's right to be familiar with new criminal offense for which he was convicted by the court, after the change of legal qualification while not being aware of it before, as well as the right to carry out the defense and present evidence about this crime. The deprivation of these rightsof the defendant, according to the Constitutional Court, is a violation of the fair process provided by the Constitution of the Republic of Albania (Article 42, paragraph 1 of the Constitution of the Republic of Albania) and the European Convention on Human Rights (Article 6, paragraph 1 of the European Convention on Human Rights).

In reaching the conclusion according to which the courts of ordinary jurisdiction, can not make the change of legal qualification of the offense, especially into a more serious offense than the one set by the prosecutor in the request for trial, when they proceed under summary judgment, the Constitutional Court, in its decision cites a number of decisions of the European Court of Human Rights, which, in this article I have considered to mention two decisions of this Court. Thus, in a decision of the European Court of Human Rights, about the nature of the judgment of the summary judgment it points out, among other things that: "a defendant must expect from the State to act in good faith and have received good considering procedural defense choices, using the opportunities provided by law. It is against the principles of legal certainty and the protection of legitimate faith of persons who are on trial that the State could, unilaterally, reduce the advantages arising from the waiver of certain rights relating to the notion of fair trial. If this waiver is made in exchange of the advantages mentioned above, it can not be considered fair after the national authorities have agreed to proceed with summary judgment, a fundamental element of the agreement between the State and the defendant can be modified to the disadvantage of the all, without his consent. In this regard, the Court notes that, if it is true that the Contracting States are not bound by the Convention to provide simplified procedures, we should consider nevertheless the fact that, when these procedures exist and apply, the principles of fair trial impose that the defendant should not be deprived arbitrarily of the advantages associated with that procedure (Decision of the European Court of Human Rights in the case Scoppola v. Italy, Application no. 10249/03).

While about changing the legal qualification of the offense, in a trial conducted according to summary judgment procedure, the European Court of Human Rights, on another issue, among others, argues that: "the right to be informed about the nature and motives of the indictment must be considered in the light of the defendant's right to prepare his defense. If the judges of the foundation, express when this right is recognized in domestic law, the opportunity to requalify the facts, they should ensure that the defendant had the opportunity to exercise their right of defense in a fair and effective manner. This means that the defendant must be informed within a reasonable time not only about the motives of the indictment, that is, the attributed material facts and on which the charge is based, but also, in a detailed manner as well, the legal qualification given to those facts "(Judgment of the European Court of Human Rights in the case Drassich v. Italy, application no. 25575/04).

As a conclusion, we can say, that, in a trial carried out according to the summary judgment procedure, the court can not change the legal qualification of the offense, in an offense different from the one presented by the prosecutor in the request for trial, especially, qualifying it as a more serious offense, because, by doing so, the court infringes unjustly 
the rights of the accused in a criminal trial. But, on the other hand, I think that the court, in a process that is being carried out under summary judgment, may change the legal qualification of the offense, in an offense easier than the one predefined by the prosecutor or it can also give innocence as, in this case, the court's decision is in favor of the defendant and his rights in the criminal process are not violated.

\section{Conclusions}

From the above analysed issues we can draw to some conclusions and recommendations. The main conclusion that can be drawn from the paper is that the Code of Criminal Procedure has not adjusted properly and in complete manner, the procedural institute of summary judgment and therefore I would recommend that by the legislator's side there should be the following amendments and legal changes in the code:

- Point 1 of article 403 of Criminal Procedure Code, to be reformulated in the following way:

"The defendant or his special representative (defender) may request that the case to be reviewed in the state the acts are".

- After point 1, of article 403 of Criminal Procedure Code, to be added another point, point 2 with the following content:

"The request for summary judgment should be made by the defendant or his special representative (defender), before the initiation of the trial".

- In article 403 of the Code of Criminal Procedure, to be added a special point, point 4, with the following content:

"Upon application of the defendant or his defender for a summary judgment, the court invites the prosecutor to submit the other acts that are not included in the case file of the judgment, as well as to express their opinion on whether or not the submitted request should be accepted".

- In article 405 of the Code of Criminal Procedure, which needs a complete reformulation, there should be carried out the following additions and legal changes:

- The first four points of this article should be abolished as unnecessary and to be replaced with the following content:

"1. In the procedure of the hearing of summary judgment, the rules that are applicable to ordinary judgment are applied as far as possible".

- The points 4 and 5 of article 405 of the Code of Criminal Procedure, should be abolished as vague and confusing and the entire procedure of judgment should be reduced and regulated according to the following provision in this article with four separate points, and particularly, points 2, 3, 4 and 5, with the following content:

2. The summary judgment hearing begins with the verification of the presence of the parties and afterwards the defendant or his defender submit the request for summary judgment, in accordance with the requirements of Article 403 of this Code.

3. Once the court receives the prosecutor's opinion on the submitted request, it takes a decision on accepting it or not, in accordance with the rules provided by Article 404 of this Code.

4. Upon acceptance of the request for summary judgment, the president of the body of judges, invites the prosecutor to express the results of preliminary investigation in a summarised manner and the evidence where it is based on, and invites the defendant and / or his defender, to express their position about the indictment and the evidence.

5. After the speech of the prosecutor and the defendant and / or his defender, the court decides to administer the acts and evidence of the investigation file and invites the parties to the final discussion."

- In article 405 of the Code of Criminal Procedure, there should be added another point, and particularly, point 8, with the following content:

"8. When during the trial that is being conducted under the summary judgment procedure, the defendant or his legal 
defender, arise claims as to the validity of acts of preliminary investigation or seek to obtain new evidence, the court decides to revoke the decision of the summary judgment and to start the trial from the beginning, based on the rules of ordinary judgment."

\section{References}

The Constitution of the Republic of Albania;

The European Convention of Human Rights ;

The Criminal Procedure Code of the Republic of Albania;

Islami H; Panda I and Hoxha A; "Criminal Procedure", Morava Publishing, Tirana 2007;

The Decision of the European Court of Human Rights, case Scoppola v. Italy, application no. 10249/03;

- The Decision of the European Court of Human Rights, case Drassich v. Italy, application no. 25575/04;

Decision no. 04 of 2012 of the Constitutional Court of the Republic of Albania;

Unifying Decision No. 02 of 29.01.2003 of the Criminal Section of the Supreme Court of Albania.

Decision no. 38 on 16.04.2013 of the Court of Appeal for Serious Crimes, Tirana;

Decision no. 14 on 03.07.2013 of the Court of Appeal for Serious Crimes, Tirana. 